\title{
Analysis of Factors Motivating to Learn a Foreign Language in Additional Education Courses
}

\author{
Natalya Podporina ${ }^{1}$, Anna Kuklina ${ }^{1}$, Lyudmila Gerasimova ${ }^{1 *}$ \\ ${ }^{1}$ Reshetnev Siberian State University of Science and Technology, Krasnoyarsk, Russia \\ "Email: lyu-gerasimova@yandex.ru
}

\begin{abstract}
Additional education provides expanding career opportunities and a variety of professional prospects. The professional retraining program "Translator in the field of professional communication" developed and implemented at the Siberian State University of Science and Technology named after Academician M.F. Reshetnev meets modern requirements for the training of high-level specialists and the needs of the personnel market. The paper considers the aspects of analysing the reasons and factors motivating students to learn a foreign language in professional retraining courses. Surveys of the participants of the educational process were carried out. Their purpose was to clarify the motives and goals of additional learning a foreign language as a tool in the professional sphere and the participants' perception of the effectiveness of obtaining the required knowledge. The features of the formation of consumer demand for the program offered by the university were studied. The analysis of the structure of groups and the dynamics of their enrolment were carried out. The survey data were processed by standard methods of statistical analysis. Such programs supported by partnerships with foreign educational organisations play a significant role in the development of an educational institution as a way to form its image.
\end{abstract}

Keywords: Professional retraining, Motivating factors, Educational service, Academic mobility, Selfdevelopment.

\section{INTRODUCTION}

Within many years learning a foreign language has not been among main purposes in Russian educational institutions. The absence of perspectives for graduates might be the reason of such a situation. Students did not want to master a language as they did not see any future possibility to use it in their work in an international company. This state of affairs remained the same even after the Soviet Union has turned into fifteen independent states [1]. But since then everything has changed considerably.

In modern Russia, obtaining first-class knowledge is prestigious and plays a significant role in building a future career. It is vital for increasing competitiveness and finding pace in the labour market. Therefore, a number of people motivated to continue their learning throughout their lives is increasing every year [2].
The system of additional education is considered to be a part of the education system for adults. The peculiarity of this system is defined by the fact that it is highly desired mainly among adults, who usually mix work with study and have secondary or higher education. They are more interested in learning if they have motivation for additional education and see the perspectives of using it for development of their careers [3]. Consequently, the educational process in additional education has several peculiarities. They are: the need for justification, realization of the bare necessity for training, usefulness, striving for independence, life experience usage, etc. [4].

Additional education is provided by several educational programs besides the major educational programs and state educational standards. It is carried out on the basis of four levels of vocational education. It is mainly a "super-basic" and often postgraduate education. 
Nowadays higher educational institutions encourage their graduates to acquire additional professional skills and to develop existing ones. Research shows that about $71 \%$ of students are faced with the necessity to have additional education, and $51 \%$ of them already received such education in parallel with their major speciality [5].

Foreign language courses offered by universities also play a significant role in providing successful future careers for graduates [6]. The analysis of modern educational standards convinces us that today's main trends in educational policy can be attributed to the actualisation of practice-oriented higher professional education. It means that a higher school graduate, besides the essential professional competencies, must have several personal skills providing effective communicative activity, working in a team, practising intercultural interaction, self-organisation, selfdevelopment, etc. In this regard, the importance of foreign-language training increases since it becomes possible through language education to solve a whole complex of methodological problems, including forming students' universal and general professional competencies and personal qualities [7].

The main aim of teaching a foreign language is to form the ability to communicate [8]. So, acquiring such additional skills as foreign languages is very important in training future specialists. Taking this fact into account, the Siberian State University of Science and Technology named after academician M.F. Reshetnev organised additional professional retraining courses "Translator in the field of professional communication" (hereinafter TPC) for bachelors and specialists, as well as for undergraduates and postgraduates. The organisation of such courses helps students to develop and improve their professional language level actively.

\section{METHODS}

The reasons and motivation for learning a foreign language were analysed using statistical data gathered surveying the students of professional retraining courses "Translator in the field of professional communication". Statistical data were processed using classification and comparative analysis. MicrosoftExcel software product was used for visual presentation of information.

\section{RESULTS}

Two surveys were conducted among students of the Siberian State University and students of the TPC program concerning the attitude towards studying foreign languages and the demand for such courses.

Students answered ten questions related to studying foreign languages and identified the circumstances that affect the necessity and need for learning foreign languages during the research. The question of motivation for learning was among the most significant ones. The students pointed out such factors as:

1. Work. Knowledge of a foreign language allows applying for a more high-paid job and the perspective of career growth or working in a foreign company.

2. Traveling. Doing it independently one can not only get new impressions and save money but also avoid popular tourist areas full of people.

3. Study. Knowledge of a foreign language presents the opportunity to study abroad and pass exams in a foreign language.

The data is presented below in Figure 1 .

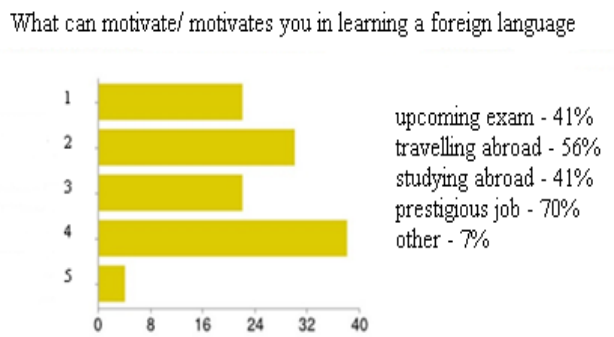

Figure 1 Motivating factors for learning a foreign language.

The following data were obtained as the answers to questions concerning the time devoted to learning a foreign language and the significance of the teacher in this process:

- the length of time devoted to learning a foreign language (72\% of respondents) is an indicator of a serious attitude towards learning;

- learning with a teacher appears to be more suitable for respondents $(70 \%)$ than independent, i.e., self-directed learning $(25 \%)$;

- learning is considered to be an auxiliary type of learning (Figure 2).

How much time do you spend on learning a foreign language?

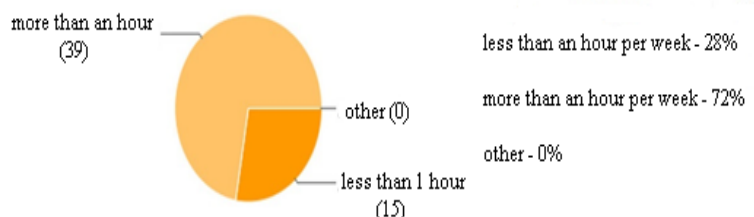

(15)

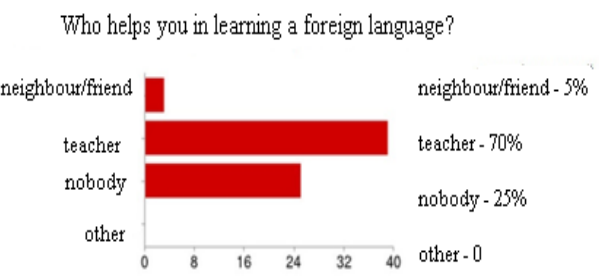

Figure 2 Attitude towards learning. 


\section{DISCUSSION}

According to the survey, students are motivated for long-term learning of a foreign language, which also indicates the demand for foreign language training courses over the last four years.

As a rule, the TPC courses are chosen by students who study at the university that organises such courses. However, according to the archival data analysis, over the last five years, in each group of TPC courses, there were from one to two percent of students who were either students of other educational institutions or already working specialists who needed foreign language skills due to their professional activities. Figure 3 shows the quantitative characteristics of TPC courses over the last four years. Representatives of technical specialities occupy approximately $51-59 \%$ of places at such courses; $24-25 \%$ of students are students of economic specialities [9].

\section{The purpose of getting additional education}

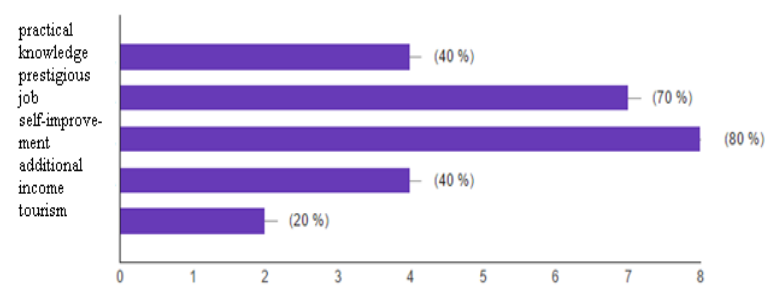

Figure 3 Quantitative characteristics of TPC courses (hereinafter referred to as FL). Temporary motivation is shown by the upcoming exam in a foreign language and travel abroad ( $41 \%$ and $40 \%$, respectively).

At the same time, it seems necessary to consider the interest of the university students in information about educational services. Mastering one or more foreign languages is one of the essential parts of preparing students for professional work. Exchanging professionally vital information not only in the native but also in a foreign language is a prerequisite for permanent professional growth [10].

The function of a foreign language as a means of professional orientation is to improve skills and abilities in professional activities and to ensure the pursuit of career prospects. Naturally, this function is realised through the organisation of the educational process, as well as the provision of additional education services.

Another analysis is related to studying the demand of the consumer audience for this educational service.

The research shows that $40 \%$ of respondents suppose additional language training to be essential for specialists in engineering, because it gives practical skills that may give better opportunities in further studying and work.

More than half of the TPC students $(60 \%$ of the respondents) would like to be taught by foreign specialists. Therefore, it is advisable for a university to actively develop partnerships with foreign universities, since the qualifications of teachers and the knowledge that they can transfer to students are very important factors when deciding on studying for an additional program

Additional language courses are especially popular with university graduates $(41 \%$ of respondents are higher university degree specialists); consequently, it can be said that communication campaigns aimed at this target audience will repay.

The second survey shows a stable interest towards getting additional higher education in foreign languages. This fact proves the students' wish to have more opportunities of getting a high-paid job (70\%). But still the majority of young people (Figure 4) look for selfimprovement ( $80 \%$ of the respondents).

According to the survey results, most respondents are first-year university students. This fact shows the desire of young people, yesterday's entrants, to selfimprovement and expanding professional opportunities.

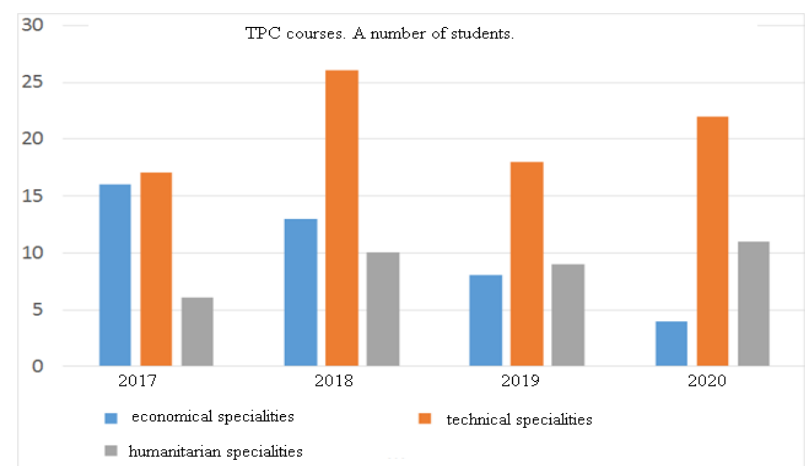

Figure 4 The purpose of getting additional education.

\section{CONCLUSION}

Thus, the professional retraining program "Translator in the field of professional communication", on the one hand, meets the primary needs of the target audience in increasing the chances of getting a prestigious job in the future, self-improvement, and expanding their opportunities, such as academic mobility, travelling. At the same time, the role of promotion as an information source about the available offers on the educational services market and as a way of forming the image of an educational institution is increasing. 


\section{REFERENCES}

[1] K.P. Chilingaryan, R.G. Gorbatenko,"Motivation in language learning"2nd International Multidisciplinary Scientific Conference on Social Sciences and Arts SGEM2015. DOI: https://doi.org/10.5593/SGEMSOCIAL2015/B12/S $\underline{3.085}$

[2] J V.V. Abraukhova, A.S. Zimovetc, "Transformation in Russian adult additional education", January 2021, E3S Web of Conferences? INTERAGROMASH 273 (2021) 12125/

DOI: https://doi.org/10.1051/e3sconf/20212731212

[3] S.A. Demina, V.A. Postyrnak,"Application prospects of distance learning technologies in the system of additional vocational education" SHS Web of Conferences 9(2016) 02012. DOI: https://doi.org/10.1051/shsconf/2016 EEIA 20162 $\underline{2902012}$

[4] T.V. Samosenkova,

E.B. Nazarenko,"Psychological and pedagogical peculiarities of teaching foreign undergraduate students at the Russian University" journal "Nauchnyy rezul'tat. Pedagogika I psikhologiya obrazovaniya" 3 (2015) 47-51.

[5] A.V. Merenkov, A.D. Sushchenko, "How University Students Develop and Meet Their Need for Additional Education" Voprosy obrazovaniya / Educational Studies. Moscow 3 (2016) 204-223. DOI:

https://vo.hse.ru/data/2016/09/19/1123209073/Mer enkov.pdf

[6] N.M. Podporina, L.A. Gerasimova, A.I. Kuklina, I.Yu. Eremina, «Analysis of methods of promoting qualification upgrading courses»// II International Conference on Economic and Social Trends for Sustainability of Modern Society - ICEST 2021// European proceedings of social and behavioural sciences $116 \quad$ (2021) 2106. DOI: https://www.europeanproceedings.com/files/data/ar ticle/10076/15139/article_10076_15139_pdf_100.p df

[7] N.I. Almazova, A.V. Rubtsova,"Productive Model of Foreign Languages Learning: Realities and Prospects" Conference: Proceedings of the International Conference Communicative Strategies of Information Society (CSIS 2018), 2019, pp. 319-324. DOI: https://doi.org/10.2991/csis-18.2019.65

[8] D.A. Radzhabova, Modern educational technologies in teaching a foreign language. Molodoj uchenyj 13(147) (2017) 592-595.
[9] A. Tenieshvili,"Knowledge of the English language as a "catalyst" for the lifelong learning process in maritime education and training"// the $26^{\text {th }}$ International Maritime Lecturers Association Conference (IMLA 26) "Modern Challenges in Maritime Education and Training" Proceedings, 2019, pp. 163-176

[10] M.H. Makhmurova, "The importance of a foreign language in higher education" journal "Voprosy nauki I obrazovaniya", 2020, pp. 15-19. 